\title{
Relation of Natural Frequencies to Traffic Pedestrians' Comfort of Some Steel Footbridges
}

\author{
Moga Cătălin, Drăgan Delia and Nerișanu Raluca
}

\begin{abstract}
In this paper several aspects regarding the dynamic behaviour of the steel footbridge structures under the action of the loads generated by the pedestrians' displacement, correlated with the traffic comfort of the pedestrians crossing the structure are presented. The crossing pedestrians' comfort criterion requires the values of vibration frequencies and accelerations of the structures in certain limits so that the vibration amplification or resonance is avoided. The paper takes under investigation eight footbridges on steel, composite steel-concrete girders and a cable stayed structure from the viewpoint of frequencies in vibration Mode 1 in a vertical plane, generated by their own weight - natural frequency, or from a partial pedestrian loading, as well as the resulting resonance risk and the traffic comfort.
\end{abstract}

Keywords - analysis of footbridges comfort, critical frequency and acceleration, dynamic response, steel and composite steel-concrete footbridges, traffic comfort.

\section{INTRODUCTION}

This paper presents several aspects related to the dynamic behaviour of the footbridge structure under the loads generated by de displacement of the pedestrians along the footbridge. The maximum comfort criterion applied to footbridge crossing requires a total absence of vibrations which could lead to less slender structures or slender structures provided with vibration damping systems, which increase the construction costs.

The paper investigates the case of eight footbridges: rolled steel girder footbridges, composite steel-concrete girders, steel-concrete composite structure with circular web hollows, girders with corrugated webs, truss girders footbridge, trapezoidal steel box girder footbridge and footbridge on cable stayed structure. The analyses are made for the frequency in the 1st Mode of vibration in vertical plane, the vibrations being the result of own weight (natural frequency) or partial footbridge loaded and consequent resulting resonance risk, respectively the traffic comfort.

The load given by the pedestrian walking or running is equivalent to a timeconcentrated force.

Conventionally, for walking, the frequency can be described by a Gaussian curve with an average value of $2 \mathrm{~Hz}$ and a standard deviation of $0.20 \mathrm{~Hz}$.

In case of transverse vibrations, the lock-in phenomenon may occur, which refers to the fact that a crowd composed of units with different frequencies tend to gradually receive a common frequency, that of the structure, and enter in phase with the movement of the bridge. 


\section{DYNAMIC ANALYSIS AND TRAFFIC COMFORT}

According to EN 1990-EC 0 - Annex A2, [1], the maximum recommended accelerations are as follows: $0.7 \mathrm{~m} / \mathrm{s}^{2}-$ vertical vibrations; $0.2 \mathrm{~m} / \mathrm{s}^{2}-$ horizontal vibrations; $0.4 \mathrm{~m} / \mathrm{s}^{2}$ - exceptional situations (agglomerations). Verification of the comfort criterion should be performed if the fundamental frequency of the structure is less than the value of 5 $\mathrm{Hz}$ for vertical vibrations and $2,5 \mathrm{~Hz}$ for horizontal (lateral) vibrations and torsional vibrations.

There are four Traffic Classes for walkways, depending on the size of the estimated traffic, Table 1, [1], [10].

Table. 1. Traffic classes

\begin{tabular}{|c|c|}
\hline Class & Traffic characteristics \\
\hline I & urban footbridges with high pedestrian density \\
\hline II & urban footbridges, occasionally loaded on the entire surface \\
\hline III & footbridges for normal use; occasionally crossed by large groups of pedestrians \\
\hline IV & footbridges occasionally crossed \\
\hline
\end{tabular}

Four conventional areas for vertical and horizontal accelerations are defined (Figure 1) in ascending order, corresponding to maximum, mean and minimum comfort levels, where field 4 corresponds to inadmissible acceleration values, [10].

Horizontal acceleration is limited to $0.10 \mathrm{~m} / \mathrm{s}^{2}$ to avoid the "lock-in" phenomenon.

ACCELERATION FOR VERTICAL VIBRATIONS

\begin{tabular}{|c|c|c|c|c|}
\hline RANGES & 0 & 1 & acc. $\left[\mathrm{m} / \mathrm{s}^{2}\right]$ & 2.5 \\
\hline 1 & MAX. & & & \\
\hline 2 & & MEAN & & \\
\hline 3 & & & MIN. & \\
\hline 4 & & & & \\
\hline
\end{tabular}

ACCELERATION FOR HORIZONTAL VIBRATIONS

\begin{tabular}{|c|c|c|c|c|c|}
\hline RANGES & $\begin{array}{ll}0 & 0.1\end{array}$ & 0.15 & 0.3 & acc. $\left[\mathrm{m} / \mathrm{s}^{2}\right]$ & 0. \\
\hline 1 & $\overline{\text { MAX. }}$ & & & & \\
\hline 2 & & $\overline{\text { MEAN }}$ & & & \\
\hline 3 & & & & $\overline{\text { MIN. }}$ & \\
\hline 4 & & & & & \\
\hline
\end{tabular}

Fig. 1. Acceleration ranges for vibrations

For footbridges that fall into classes I, II and III, it is necessary to calculate the natural vibration frequency of the structure. Frequencies are determined for two mass assumptions of the system: unloaded footbridge; the bridge loaded on the walkway with $700 \mathrm{~N} / \mathrm{m}^{2}$.

Vertical and horizontal frequencies may fall into four areas of the resonance risk, Figure 2, [10], where: Domain 1: maximum resonance risk; Domain 2: average (mean) resonance risk; Domain 3: low resonance risk; Domain 4: negligible resonance risk.

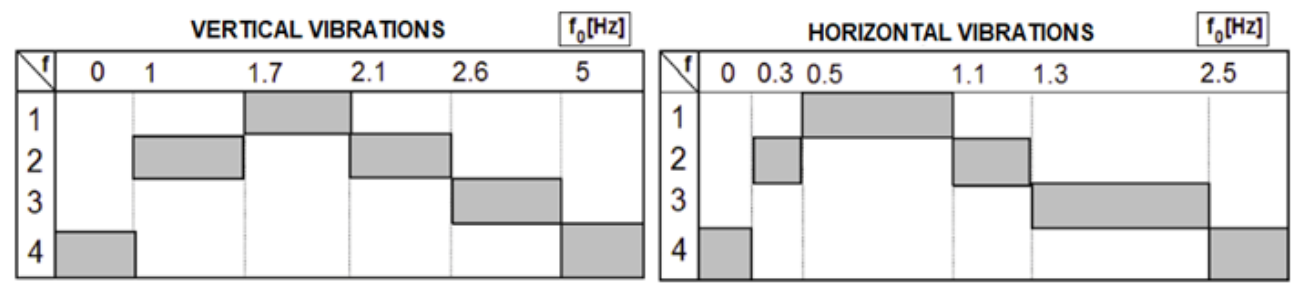

Fig. 2. Frequency ranges for vibrations 


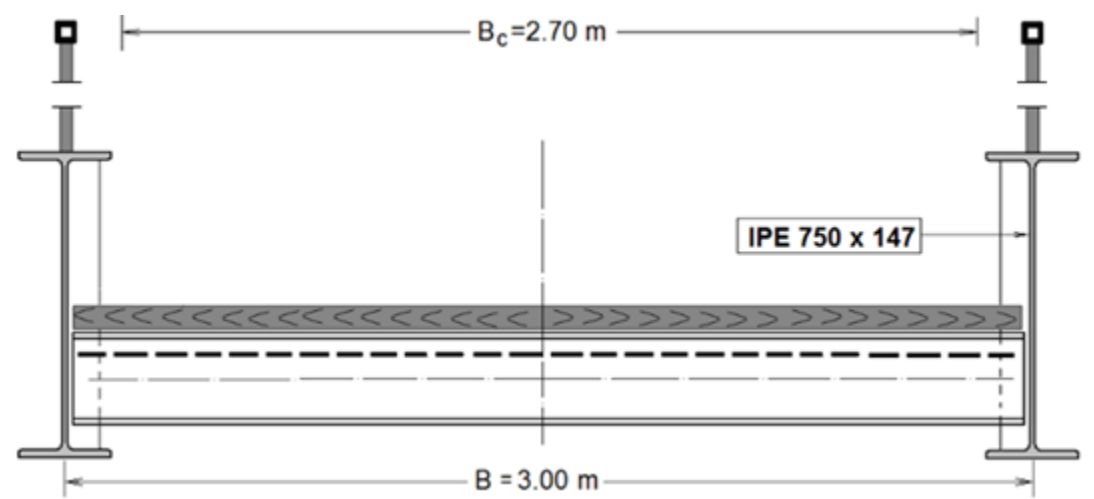

Fig. 3. Footbridge structure on rolled beams

\section{P3: Footbridge with composite steel-concrete structure}

The composite steel-concrete deck of the footbridge has the following design data: span: $\mathrm{L}=24.0 \mathrm{~m}$; effective width of $3.00 \mathrm{~m}$. The deck is made of two main beams with a steel-concrete composite section and the composite transverse beams with a monolithic reinforced concrete slab of $12 \mathrm{~cm}$ thick, Figure 4.
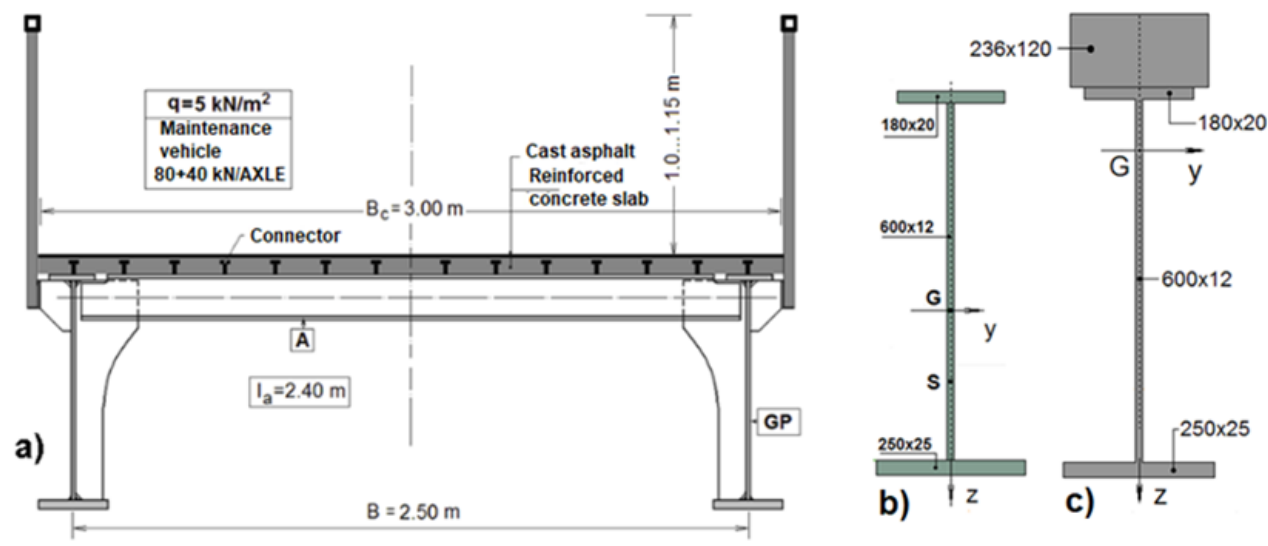

Fig. 4. Superstructure of a composite footbridge

a) Deck cross-section; b) Steel-beam cross-section; c) Composite design cross-section

P4: Footbridge with a composite steel-concrete structure using unsymmetrical steel beams with circular holes

The analysis of a composite steel-concrete structure is performed for a footbridge, knowing the design data: the span: $\mathrm{L}=24.0 \mathrm{~m}$; effective width $\mathrm{Bc}=3.00 \mathrm{~m}$, thickness of the concrete slab is of $12 \mathrm{~cm}$. The deck is made of two main beams with steel-concrete composite section, made from rolled profiles with circular holes in the webs, welding different rolled elements for the two parts, Figure 5. 


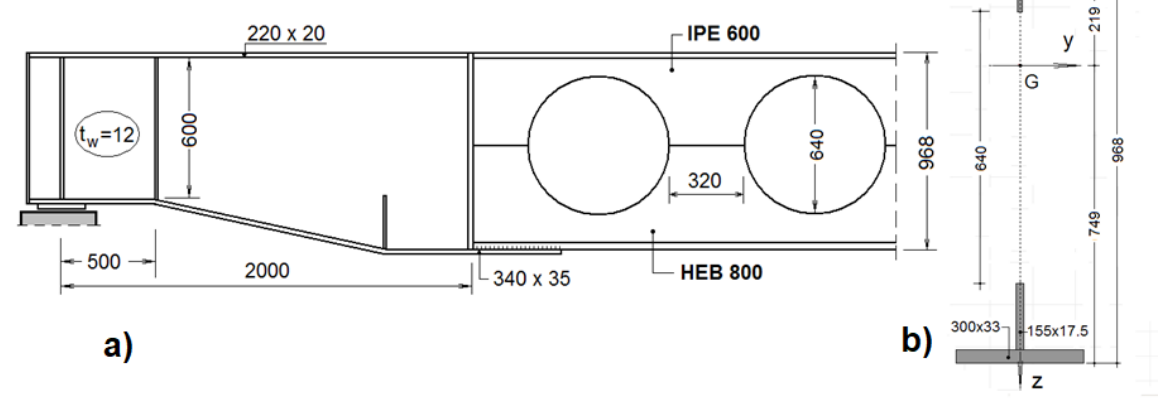

Fig. 5. Main beams with web holes: a) steel component; b) composite design cross-section

\section{P5: Footbridge with steel beams with trapezoidal webs}

In the case of the main beams with the web made of trapezoidal plate the solution presented in Figure 6 is chosen as a cross-section and the main beams are presented in Figure 7.

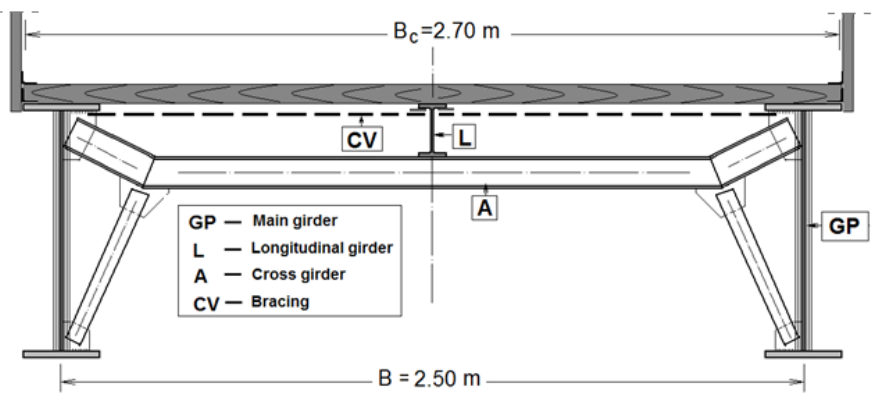

Fig. 6. Superstructure on beams with trapezoidal webs

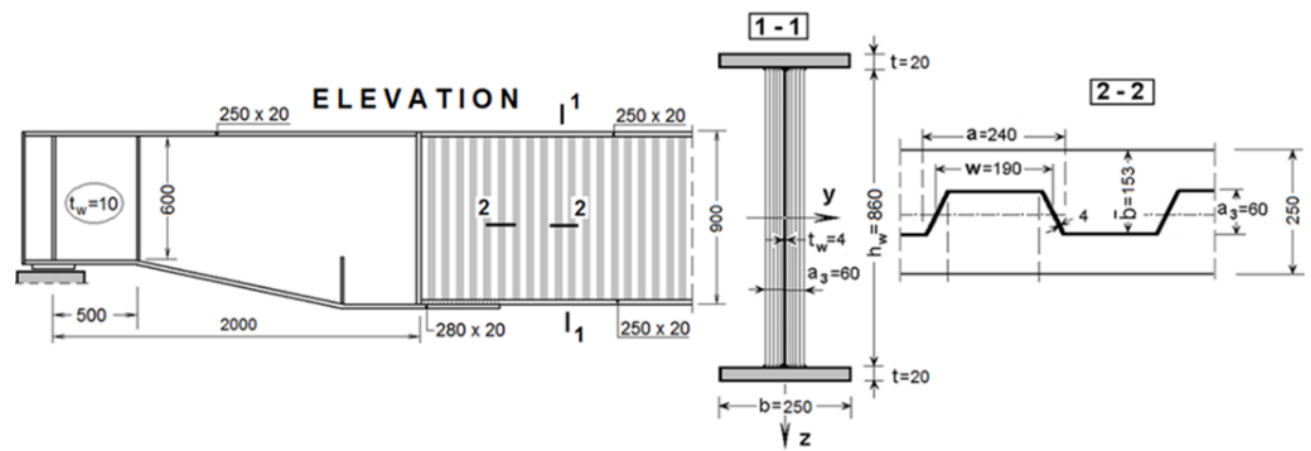

Fig. 7. Main beams of the footbridge with trapezoidal webs

\section{P6: Truss girder footbridge}

The geometric scheme of the main trusses and the cross section chosen for this case are shown in Figure 8. 


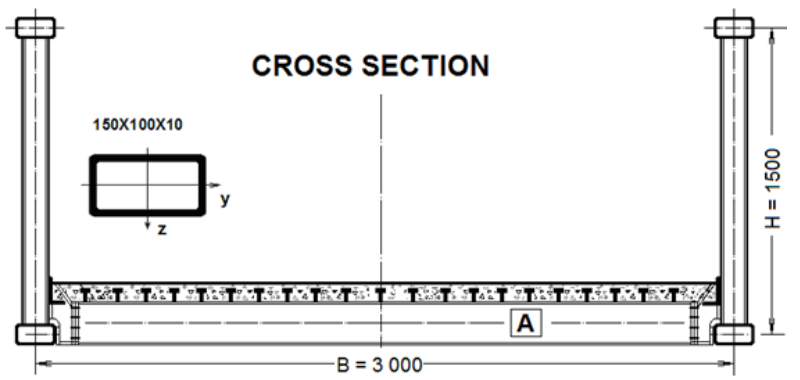

Fig. 8. Truss girder footbridge

\section{P7: Footbridge across the Someș River in Cluj-Napoca}

The solution adopted is that of a composite steel-concrete superstructure where the steel part is a box beam and the flooring is a monolithic reinforced concrete slab. The footbridge has a span of $58.0 \mathrm{~m}$ and a width of $6.0 \mathrm{~m}$, that ensures two pedestrian sidewalks and a cycle track located in the central area, Figure 9, [2], [12].

Table 3 centralizes the natural frequencies obtained for the vertical vibrations Mode 1 for the analyzed structures, the resonance risk range in which they can fall.

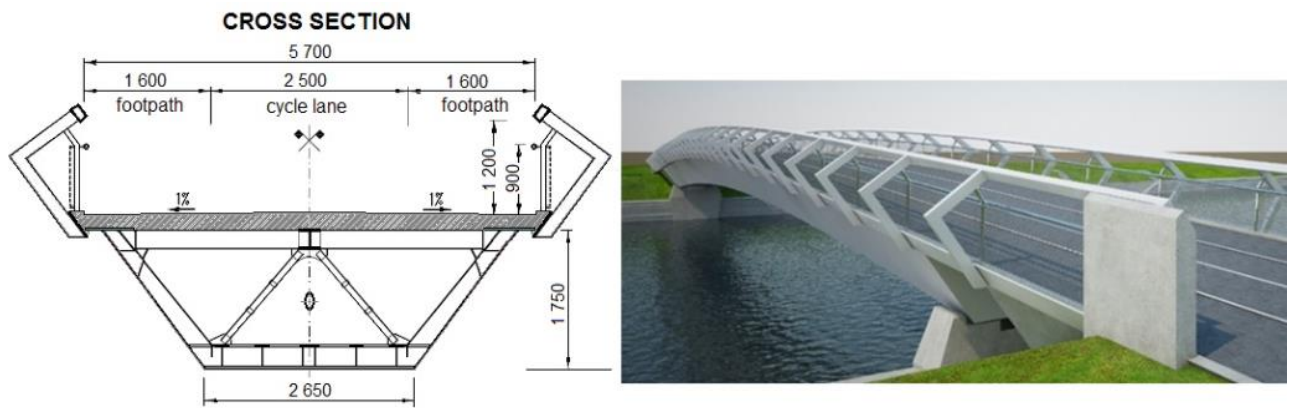

Fig. 9. Footbridge cross-section and 3D rendering

Table. 3. Synthesis of analysis

\begin{tabular}{|c|c|c|c|}
\hline $\begin{array}{c}\text { Analyzed } \\
\text { footbridges }\end{array}$ & Main beams & $\begin{array}{c}\text { Natural } \\
\text { frequencies } \\
\text { (sup./inf.) } \\
\mathbf{f}_{\mathbf{1}}[\mathbf{H z}]\end{array}$ & $\begin{array}{c}\text { Resonance } \\
\text { domain risk }\end{array}$ \\
\hline P1 & Rolled IPE 750. L=24 m & $3.39 / 3.08$ & Low resonance risk \\
\hline P2 & Rolled IPE 500. L=24 m & $2.24 / 1.95$ & $\begin{array}{c}\text { Mean/maximum } \\
\text { resonance risk }\end{array}$ \\
\hline P3 & $\begin{array}{c}\text { Welded steel beams. Composite steel- } \\
\text { concrete structure. } \mathrm{L}=24 \mathrm{~m}\end{array}$ & $2.30 / 2.29$ & Mean resonance risk \\
\hline P4 & $\begin{array}{c}\text { Steel beams with circular holes. } \\
\text { Composite structure. } \mathrm{L}=24 \mathrm{~m}\end{array}$ & $3.98 / 3.97$ & Low resonance risk \\
\hline P5 & Steel girder with corrugated webs. L=24 m & $3.80 / 3.40$ & Low resonance risk \\
\hline P6 & Steel truss girders. L=24 m & $3.13 / 3.02$ & Low resonance risk \\
\hline P7 & $\begin{array}{c}\text { Trapezoidal steel box beam. Composite } \\
\text { steel-concrete structure. L=58m }\end{array}$ & $1.38 / 1.24$ & Mean resonance risk \\
\hline
\end{tabular}


P8: Dynamic analysis of a footbridge structure over the Someș River

The dynamic response of a footbridge over the Someș River in Satu Mare Municipality, on a central arch have been analyzed in a Feasibility Study [12]. The footbridge superstructure, [2], [12] has 3 spans, Figure 10, with a central span of $130.0 \mathrm{~m}$.

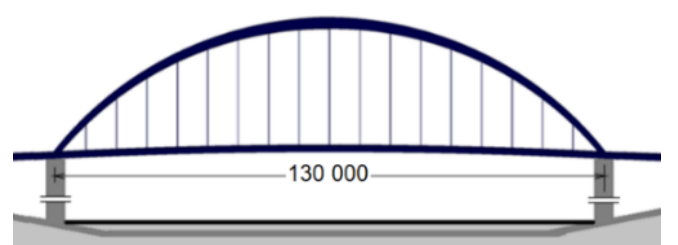

Fig. 10. Footbridge longitudinal view (elevation)

Vibration mode 1, in the vertical plane

The footbridge falls within Class II: urban footbridges, occasionally loaded on the entire surface. The deck cross-section analyzed in the first step is presented in Figure 11.

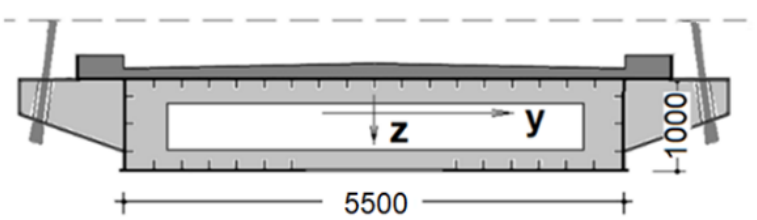

Fig. 11. Deck cross-section

The frequencies for Vibration Mode 1: superior frequency - $\mathrm{f}_{1}=38 \mathrm{~Hz}$; inferior frequency $-\mathrm{f}_{1}=37 \mathrm{~Hz}$. The frequencies for Vibration Mode 1 fall within Domain 4.

\section{Vibration Mode 1, in the horizontal plane}

The frequencies for Vibration Mode 1: superior frequency - $\mathrm{f}_{1}=0.52 \mathrm{~Hz}$; inferior frequency $-\mathrm{f}_{1}=0.51 \mathrm{~Hz}$. The frequencies corresponding to Vibration Mode 1 fall within Domain 1: maximum resonance risk. Considering that the footbridge deck has lateral cantilevers we verified if the dynamic parameters corresponding to the horizontal vibrations can be modified using longitudinal ties with a tubular cross-section.

\section{Vibration mode 1 in the horizontal plane - horizontally stiffened deck}

The deck cross-section, with the new cantilever system is presented in Figure 12.

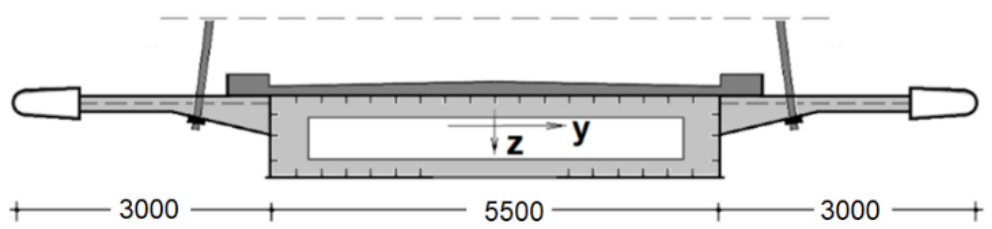

Fig. 12. Deck cross-section reinforced with longitudinal ties

Table 4 centralizes the superior frequencies and the resonance risk for the two analyzed decks, for the case of unloaded structure and the case of partially loaded structure [2]. 
sciendo

14 Ovidius University Annals Series: Civil Engineering, Year 23, 2021

Table 4. Mode 1- Frequencies and the resonance risk.

\begin{tabular}{|c|c|c|c|c|}
\hline $\begin{array}{l}\text { The } \\
\text { deck }\end{array}$ & Vibration mode & Frequency & $\begin{array}{l}\text { Freq } \\
{[\mathrm{Hz}]}\end{array}$ & $\begin{array}{c}\text { Resonance } \\
\text { risk. } \\
\text { Observations }\end{array}$ \\
\hline \multirow{4}{*}{ 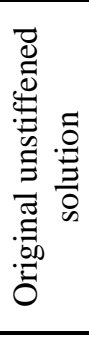 } & \multirow{2}{*}{$\begin{array}{l}\text { Vibration mode } 1 \text { in the } \\
\text { vertical plane }\end{array}$} & $\begin{array}{l}\text { Superior frequency. } \\
\text { Unloaded footbridge }\end{array}$ & 38 & \multirow{2}{*}{$\begin{array}{l}\text { Domain 4: } \\
\text { Negligible } \\
\text { resonance risk }\end{array}$} \\
\hline & & $\begin{array}{l}\text { Superior frequency. } \\
\text { Partially loaded footbridge }\end{array}$ & 37 & \\
\hline & \multirow{2}{*}{$\begin{array}{l}\text { Vibration mode } 1 \text { in the } \\
\text { horizontal plane }\end{array}$} & $\begin{array}{l}\text { Superior frequency. } \\
\text { Unloaded footbridge }\end{array}$ & 0.52 & \multirow{2}{*}{$\begin{array}{l}\text { Domain 1: } \\
\text { Maximum } \\
\text { resonance risk }\end{array}$} \\
\hline & & $\begin{array}{l}\text { Superior frequency. } \\
\text { Partially loaded footbridge }\end{array}$ & 0.51 & \\
\hline \multirow{3}{*}{ 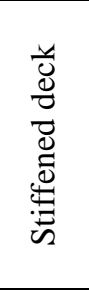 } & \multirow{2}{*}{$\begin{array}{l}\text { Vibration mode } 1 \text { in the } \\
\text { horizontal plane } \\
\text { Interrupted deck at the } \\
\text { intermediate supports }\end{array}$} & $\begin{array}{l}\text { Superior frequency. } \\
\text { Unloaded footbridge }\end{array}$ & 1.18 & \multirow{2}{*}{$\begin{array}{l}\text { Domain 2: } \\
\text { Mean } \\
\text { resonance } \\
\text { risk. }\end{array}$} \\
\hline & & $\begin{array}{l}\text { Superior frequency. } \\
\text { Partially loaded footbridge }\end{array}$ & 1.15 & \\
\hline & $\begin{array}{l}\text { Vibration mode } 1 \text { in the } \\
\text { horizontal plane. }\end{array}$ & $\begin{array}{l}\text { Superior frequency. } \\
\text { Unloaded footbridge }\end{array}$ & 1.50 & $\begin{array}{l}\text { Domain 3: } \\
\text { Low } \\
\text { resonance risk }\end{array}$ \\
\hline
\end{tabular}

\section{CONCLUSIONS}

In the case of footbridges, in addition to checks for the ultimate limit state and service limit states, it is necessary to check pedestrian traffic comfort in direct correlation with the vibration frequency of the structure (resonance risk) and its acceleration. If these characteristics (frequency and acceleration) are in the critical area, measures must be taken to alter their value so that they fall within the limits of the recommended norms or other recognized technical materials.

\section{REFERENCES}

[1] Moga P., Guţiu Şt., Moga C. (2020), Pasarele pietonale, Ed. U.T. PRESS, Cluj-Napoca [2] Guțiu Şt. I., Moga C., Danciu A. (2019), Dynamic analysis of a footbridge structure on a central arch, Article No 5, Romanian Journal of Transport Infrastructure, Vol.8, No.2 58

[3] Moga C., Drăgan D., Nerişanu R. (2018), Comparative analyze concerning the dynamic response of some footbridge structures with steel main girders: Buletinul Univ. Tehn. „Gh. Asachi”. Vol. 64. Nr. 4, pag. 123 - 140

[4] Moga P., Guţiu Şt. I., Anghel F., Moga C., Danciu A. (2016), Footbridge over the Somes River in Cluj-Napoca, Romania. The $9^{\text {th }}$ International Conference "Bridges in Danube Basin", 2016, published in "Procedia Engineering 156 (2016)" ELSEVIER

[5] Moga P., Drăgan D., Moga C. (2015), Composite Steel-Concrete Footbridges on Girders with Circular Holes. Buletinul Univ. Tehnice „Gh. Asachi”.Tomme: LXI (LXV). Fascicle: 3, pag. $47-60$

[6] Moga P., Drăgan D. (2014), Constructive solutions and comments regarding steel girder footbridges. Buletinul Univ. Tehnice „Gh. Asachi” Tomme: LX (LXIV). Fascicle: 1, pag. $99-109$ 
[7] Suciu M., Drăgan D., Nerișanu R. (2018), Relation between dynamic response and the traffic comfort of some footbridges on plate girders, The $18^{\text {th }}$ International Multidisciplinary Scientific Geoconference (SGEM 2018), Albena-Bulgaria, Conference Proceedings, Volume 18, Nano, Bio, Green and Space - Technologies for a Sustainable Future, Issue 6.3, pag. 681 688

[8] *** FIB Bulletin 32 (2005), Guidelines for the design of footbridges

[9] *** Sétra, (2006) Footbridges - Assessment of Vibration Behaviour of Footbridges under Pedestrian Loading, Association Française de Genie Civil, Paris

[10] *** Sétra (2006), Technical guide. Footbridges. Paris

[11] *** SR EN 1990. Bazele calculului structurilor

[12] *** Proiecte realizate de XC PROJECT şi SC DRUMEX din Cluj-Napoca

Note:

Nerișanu Raluca - Technical University of Cluj-Napoca, 28 Memorandumului Street, 400114-ClujNapoca, Romania (corresponding author to provide phone: +40-728-671024; e-mail: Raluca.Nerisanu@cfdp.utcluj.ro).

Moga Cătălin - Technical University of Cluj-Napoca, 28 Memorandumului Street, 400114-Cluj-Napoca, Romania (e-mail: Catalin.Moga@ dst.utcluj.ro).

Drăgan Delia - Technical University of Cluj-Napoca, 28 Memorandumului Street, 400114-Cluj-Napoca, Romania (e-mail: Delia.Dragan@cfdp.utcluj.ro). 